\title{
Genetic structure and history of Swiss maize (Zea mays L. ssp mays) landraces
}

\section{Journal Article}

\section{Author(s):}

Eschholz, T. W.; Stamp, P.; Peter, R.; Leipner, J.; Hund, Andreas (D)

Publication date:

2010

Permanent link:

https://doi.org/10.3929/ethz-b-000017325

Rights / license:

In Copyright - Non-Commercial Use Permitted

Originally published in:

Genetic resources and crop evolution 57(1), https://doi.org/10.1007/s10722-009-9452-0 


\title{
Genetic structure and history of Swiss maize (Zea mays L. ssp. mays) landraces
}

\author{
T. W. Eschholz $\cdot$ P. Stamp $\cdot$ R. Peter $\cdot$ J. Leipner $\cdot$ \\ A. Hund
}

Received: 6 February 2009/Accepted: 25 May 2009/Published online: 28 June 2009

(C) Springer Science+Business Media B.V. 2009

\begin{abstract}
Between 1930 and 2003 with emphasis on the 1940s maize landraces (Zea mays L. ssp. mays) from all over Switzerland were collected for maintenance and further use in a new Swiss breeding program. The genetic relationship and diversity among these accessions stored in the Swiss gene bank is largely unknown. Our hypothesis was that due to the unique geographic, climatic, and cultural diversity in Switzerland a diverse population of maize landraces had developed over the past three centuries. The aims were to characterize the genetic diversity of the Swiss landraces and their genetic relationship with accessions from neighbouring regions as well as reviewing their history, collection, and maintenance. The characterization and grouping was based on analyses with ten microsatellite markers. Geographic, cultural, and climatic conditions explained a division in two distinct groups of accessions. One group consisted of landraces collected in the southern parts of Switzerland. This group was related to the Italian Orange Flints. The other group contained accessions from northern Switzerland which were related to Northern European Flints in particular German Flints. Historic evidence was found for a frequent exchange of landraces
\end{abstract}

T. W. Eschholz · P. Stamp · R. Peter - J. Leipner ·

A. Hund $(\bowtie)$

ETH Zurich, Institute of Plant Sciences, Universitätstrasse

2, 8092 Zurich, Switzerland

e-mail: andreas.hund@ipw.agrl.ethz.ch within the country resulting in a lack of regionspecific or landrace-specific genetic groups. The relatively large separation between the accessions, indicated by high $F_{\mathrm{ST}}(0.42)$, might be explained partly by a bottleneck during the collection and maintenance phase as well as by geographical and cultural separation of north and south of the country. Due to the high genetic diversity, the accessions here are a potential resource for broadening the European flint pool.

Keywords Corn/maize · Flint - Germplasm collection · History $\cdot$ Landrace $\cdot$ Open pollinated variety $\cdot$ Rheintaler $\cdot$ Zea mays

\section{Introduction}

Since the introduction of maize from the new world, a population of landraces had developed in Switzerland that was comparably diverse, given the small country size of about $41,000 \mathrm{~km}^{2}$. The reason of this huge diversity is the separation of the country into three major regions: A warm and humid southern part, almost continental central valleys and the cool and humid north. Equally, language barriers and local preferences separated the germplasm exchange among these regions as we will show. Importantly, the Swiss gene bank harbours a comparably large collection of these landraces of about 170 accessions which have not been systematically described yet. 
How do these accessions differ and where do they originate? To understand the origin of Swiss maize landraces, the history of the introduction of maize into Europe is of central importance.

The most accepted hypothesis is the introduction of maize into Europe by Columbus through Spain. Originally it was postulated that maize had slowly migrated northwards and adapted to the long day conditions and cooler climate (for a review see Dubreuil et al. 2006). Later, this view was revised and more than one introduction was postulated, first based on morphology (Finan 1948; Brandolini 1970) and later based on isozymes (Revilla et al. 1998, 2003) and SSR data (Dubreuil and Charcosset 1999; Rebourg et al. 2003; Dubreuil et al. 2006). Rebourg et al. (2003) compared a sample of 129 European populations with a sample of 88 American populations previously identified as potential regions of origin for European maize. They found that a better adapted material from the east coast of North America, the so called Northern Flint, served as primary source for maize adapted to the climate of Central Europe. Based on a historical survey Dubreuil et al. (2006) postulated an introduction of these north-eastern American maize types into Europe at the beginning of the sixteenth century. This hypothesis is supported by the fact that, already half a century after the return of Columbus, maize was extensively cultivated in the North of the Alps (for review see: Dubreuil et al. 2006) and even earlier south of them (Janick and Caneva 2005). At least two additional sources of flint maize may have been important for the adaptation to the northern European conditions, namely the introduction of the photoperiodic insensitive Cateto types from Argentina and Peru into the Italian Orange Flint populations (Rebourg et al. 2003) and the possible introduction of Pearl White Flint from Latin America to the Veneto region in Italy (Brandolini 1970; Brandolini and Brandolini 2001). The time of the introduction of maize from South America into Europe was probably towards the end of the sixteenth century as the first scientific expedition was organized in 1570 (Revilla et al. 2003). All these sources may have been important for the introduction of maize into the Swiss regions. Therefore, we hypothesised that (1) the hybridization of these different sources led to the evolution of Swiss landraces and (2) the fragmentation of the country by high mountain ridges, resulting in large cultural, lingual, and climatic diversity, favoured a subsequent differentiation of the material.

In recent years the genetic diversity of ex situ conserved European maize landraces has been extensively studied using genetic (Dubreuil and Charcosset 1999; Rebourg et al. 1999, 2003, 2001; Gauthier et al. 2002; Gouesnard et al. 2005; Reif et al. 2005b; Camus-Kulandaivelu et al. 2006; Dubreuil et al. 2006) and morphologic descriptors (Brandolini and Brandolini 2001; de Galarreta and Alvarez 2001). Landraces from Switzerland and adjacent regions of Austria, however, were under-represented in the European maize collections (cf., Gauthier et al. 2002). Landraces from the Swiss, Austrian, and German regions along the alpine Rhine river contributed to building up the current flint pool (Messmer et al. 1992). Still they might contain untapped genetic variation which could serve as a valuable genetic resource to broaden the genetic base of flint maize in European breeding. Currently, the European flint breeding pool, is on a narrow genetic base (Messmer et al. 1992; Gouesnard et al. 2005; Reif et al. 2005a) compared to the dent breeding material in use. A large amount of genetic diversity within the Swiss landrace collection can be expected, potentially harbouring new alleles for broadening the genetic base of the flint breeding pool. The aims of this study were (1) to characterize these landraces genetically in order to elucidate the structure of the entity of accessions and the genetic diversity within the country as well as the genetic relationship with accessions from neighbouring regions and (2) to review the history of Swiss maize landraces, in order to support the interpretation of the genetic characterization.

\section{Materials and methods}

Plant material

A total of 186 (Zea mays L. ssp. mays) landrace accessions from seven different geographic regions were evaluated (Fig. 1). The major part was provided by the Swiss gene bank (prefix 001-150, Banque de Gènes Nationale, Agroscope ACW, Changins, Switzerland) and by the gene bank of Tyrol (A1-A14 Genbank des Landes Tirol, Innsbruck, Austria). Additional material was obtained from other 
organizations. The material included also accessions from neighbouring countries: one accession from France (Lavaur, 040F), one from Germany (Gelber Badischer Landmais, 127D), and 15 from Austria (A). A modern flint $x$ dent hybrid was used as reference genotype for the analysis of genetic diversity (Magister, Syngenta, Basel, Switzerland). A complete list of the accessions from the Swiss gene bank can be retrieved using the advanced search form at http://www.bdn.ch/ search_form. You can chose "search in accessions" in the advanced search form and select our "NAP number" $02-201$ to retrieve these 164 accessions. The whole list may be downloaded as comma delimited text file (CSV). The accession number used here, identifies entries in the Swiss National Database (Last part of the variety code/PLCODE; e.g. $086 \mathrm{LV}$ is variety code 13-001-86). The material was multiplied in 2003 at the field station of the ETH Zurich (Eschikon, Switzerland) by crossing 50 plants at random, avoiding self pollination.

Genetic analysis

For DNA extraction, leaf material from 12 seedlings per accession was harvested separately at the three leaf stage. The leaves were cut, immediately frozen in liquid nitrogen, lyophilized for $48 \mathrm{~h}$, and stored at room temperature until further processing. The DNA was isolated with an extraction kit (Nucleo Spin
Plant, Macherey Nagel, GmbH \& Co. KG, Düren, Germany) as described earlier (Eschholz et al. 2008).

One SSR marker for each of the ten chromosomes was chosen from the Maize Genetics and Genomics Database (MGDB, Lawrence et al. 2004). The SSR markers were bmc1337, bnlg249, dupssr12, dupssr14, phi109642, phi087, umc1033, umc1125, umc1930, umc1970 (for further details see Eschholz et al. 2008). Amplification was done with a thermal cycler (Mastercycler, Eppendorf, Hamburg, Germany) applying a standard SSR program with annealing temperatures adjusted for individual primers using Taq polymerase, self-adjusting $\mathrm{Mg}^{2+}$ buffer, and dNTPs (Eppendorf AG, Hamburg, Germany).

The PCR products were visualized on $4 \%$ agarose gels (Agarose High Resolution, Roth, Karlsruhe, Germany). Digital images of the gels were analyzed using Gel-Pro Analyzer 4.5 (Media Cybernetics, Silver Spring, MD, USA). Allele size determination and identification of possible null alleles were done as described earlier (Eschholz et al. 2008).

\section{Statistics}

The molecular data were analyzed with the Powermarker 3.25 software (Liu and Muse 2005). The $F$ statistic (Theta) and the corresponding confidence interval for the loci polymorphic across all accessions
Fig. 1 Major regions of historic maize cultivation in Switzerland and the collection sites of the landrace accessions stored in the Swiss gene bank (closed circles). Regions are $A R$ Anterior Rhine, $L V$ Linth valley, $P V$ Poschiavo valley, $P R$ Posterior Rhine (Domleschg valley), $R V$ Rhine valley, $T M$ Ticino and Mesolcino, VS Valais. Background: $2008^{\odot}$ swisstopo

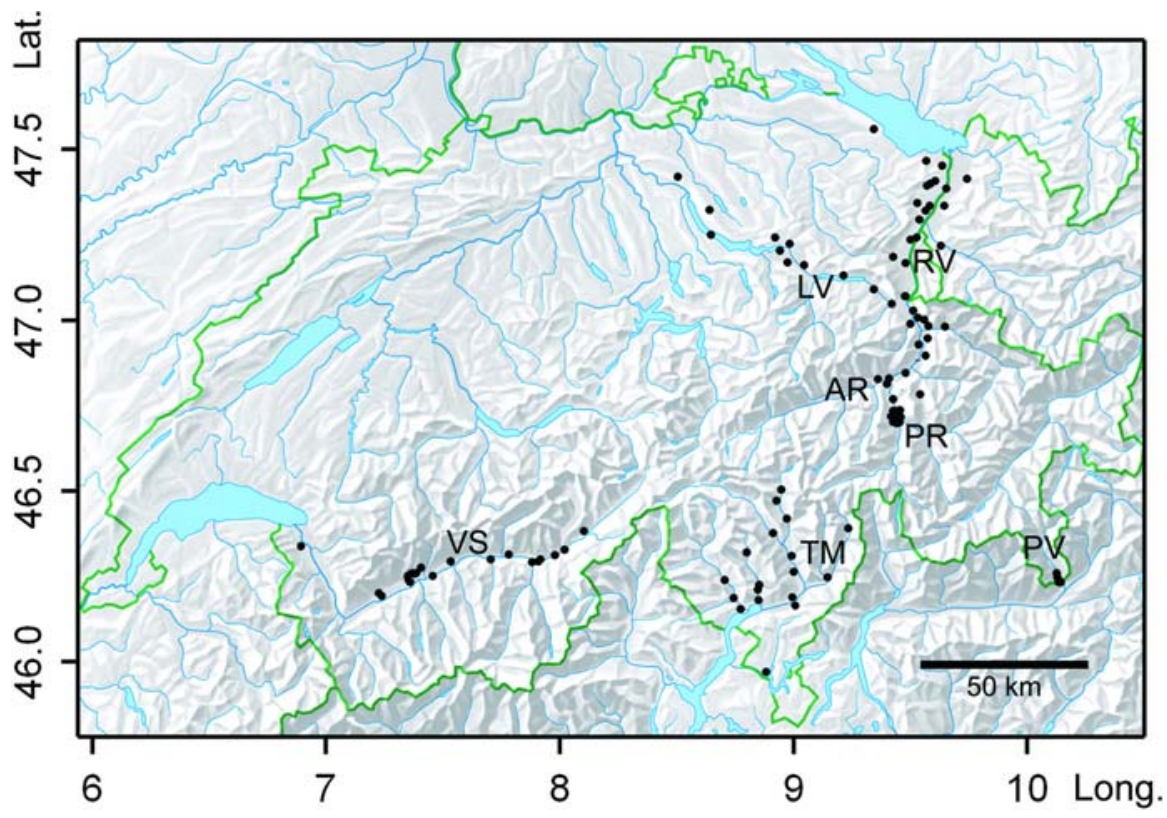


were calculated based on 1,000 bootstrap repetitions to estimate the confidence interval. The specific allele's ratio was introduced to measure the amount of specific alleles per region. For the different regions it was determined by dividing the number of alleles specific for a region by the number of accessions within that region.

Pairwise genetic distances between accessions were calculated as modified Rogers' Distance $\left(D_{\mathrm{W}}\right)$ according to Wright (1978). The minimum variance method developed by Ward (1963) was applied to cluster the accessions. The allele frequency distributions, overall and by region, and the hierarchical clustering analysis across all accessions were calculated using $\mathrm{R}$ software 2.0.1 ( $\mathrm{R}$ development core team 2004).

Gene diversity was estimated according to Weir (1996) as:

$\widehat{D}_{l}=\left(1-\sum_{u=1}^{k} \tilde{p}_{l u}^{2}\right) /\left(1-\frac{1+f}{n}\right)$

where $D_{l}$ is the unbiased estimator for gene diversity at the $l$ th locus, $n$ the number of individuals, $u$ the number of alleles for a certain locus, $p$ the accession frequency of the $u$ th allele of the $l$ th locus, and $f$ is the inbreeding coefficient estimated by the method of moments (Weir 1996).

The pairwise Cavalli-Sforza and Edwards' (1967) chord distance based on allele frequencies per region served as a basis for cluster analysis followed by 1,000 bootstrap repetitions and allowed to test for the relationships among regions of origin. For the cluster analysis of the regions the unpaired grouping method using arithmetic means (UPGMA, Sokal and Michener 1958) and the neighbor-joining (NJ) method (Saitou and Nei 1987) were compared and showed nearly identical results. The Cavalli-Sforza and Edwards' chord distance between regions as well as the bootstrapping procedure were calculated with Powermarker. The software Treefinder (Jobb et al. 2004) was used to compute and display a consensus tree. The threshold for display of bootstrap support was set to the default value $(50 \%)$.

Literature search

For the history of the collection, the original information supplied with the collected material was reviewed and presented in the results. Most of the historic material was supplied by the Agroscope Reckenholz-Tänikon Research Station ART, Zurich, Switzerland.

\section{Results}

Genetic characterization of accessions, population structure, and diversity

The marker data of all 2,172 individuals were highly informative, with average polymorphism information content (PIC) of 0.76. Treating possible null alleles as missing data resulted in $10 \%$ of missing data. Altogether 135 alleles were scored with an average of 13.5 alleles per locus (Table 1); the minimum was nine alleles per locus (umc1125) and the maximum 20 (umc1033). Allele frequencies per accession and locus ranged from 0.04 to 1 with a mean value of 0.34 . The average frequency of the most frequent alleles (present in more than $78 \%$ of accessions) was 0.58. Five alleles $(3.6 \%)$ were specific for single accessions and showed a mean frequency of 0.47 . All rare alleles (present in max. $5 \%$ of all accessions) had a mean frequency of 0.25 and rare alleles specific to certain regions had 0.22 (data not shown). The amount of allelic diversity was variable within the studied accessions. The average number of alleles per accession ranged from $1.2(040 \mathrm{~F})$ to 4.7 (142RV). The average frequency of the major allele (the allele with the highest frequency) per accession ranged from 0.45 to 0.93 with an average of 0.67 .

The Swiss landraces (Table 1) were characterized by a broad genetic diversity: Out of the 135 alleles that could be scored in this study a total of 37 were not detected in the accessions from neighbouring countries and were considered to be exclusive for Swiss accessions. When comparing accessions across their region of origin, three Swiss regions (Rhine valley, Ticino, and Valais) each harboured more than 100 alleles. Most region-specific alleles within the Swiss material were observed for material from Ticino (seven alleles, specific allele's ratio of 0.26 ) and the Rhine valley (five alleles, s.a.r. 0.09); the highest proportion of region-specific alleles was found for the Poschiavo valley (two alleles, s.a.r. 0.29; Table 1). 


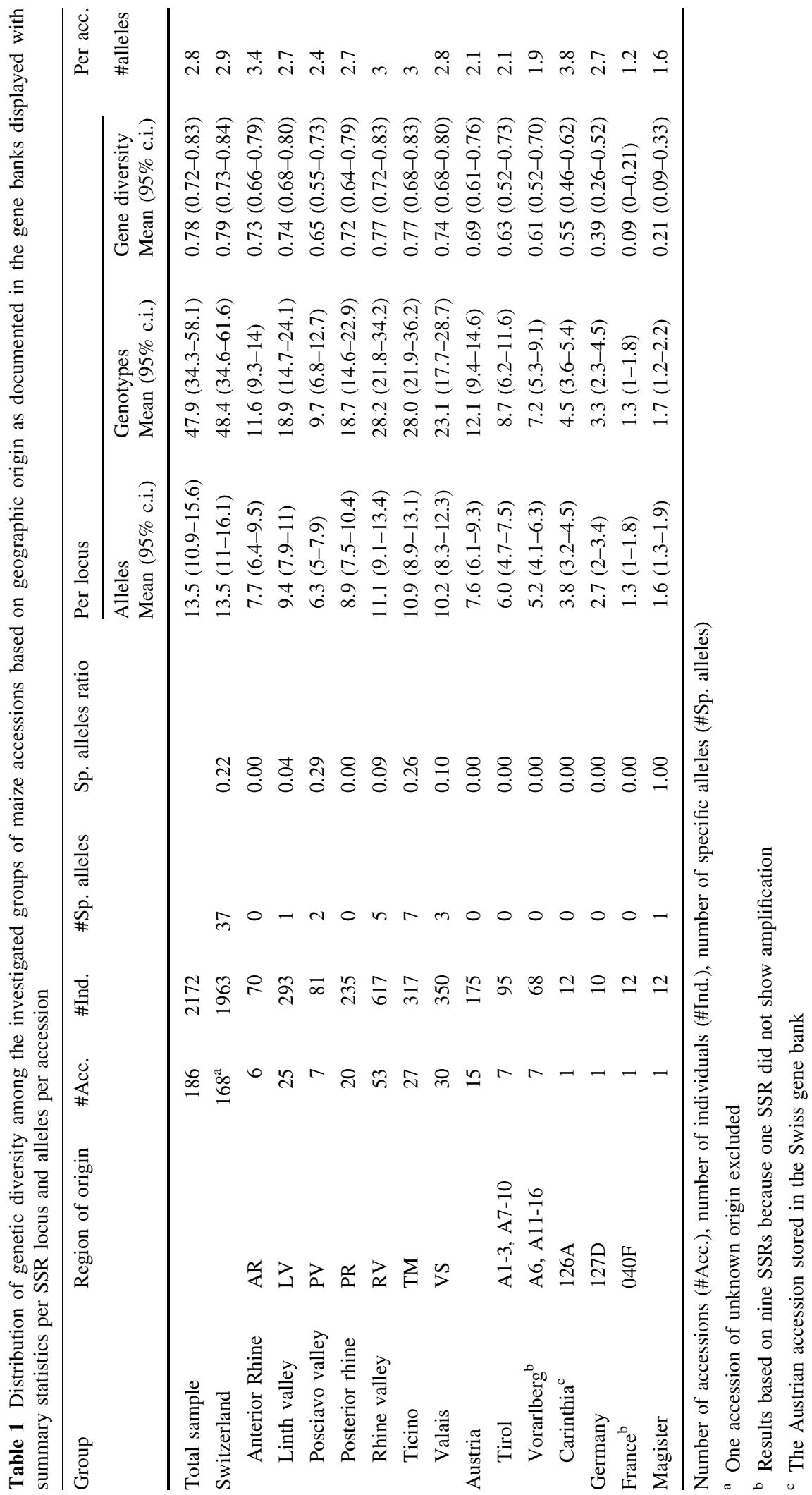


The pairwise modified Rogers' distance between the accessions ranged from 0.063 to 0.289 with an average of 0.18 . Nine pairs of accessions were separated by very small $D_{\mathrm{w}}(<0.09)$ indicating descent from a common ancestral landrace in the recent past. One of these pairs (A13 and A14) was collected at the same location and six were collected in the same geographical region (147RV and 148RV, 148RV and 149RV, 038VS and 039VS, 008PR and 138AR, 140RV and 141RV, 034VS and 113VS). Similarly small genetic distances between accessions were observed between Austrian and Swiss material (137AR and A03, 086LV and A12).

Hierarchical clustering of single accessions including accessions from Austria (Fig. 2) on the basis of pairwise $D_{\mathrm{W}}$ revealed two main groups (A and B), which were again divided into subclusters. One subcluster (A2b) of group A harboured almost exclusively southern accessions (Ticino and Poschiavo valley; Fig. 3a). Apart from this north-south contrast, there was no clear grouping according to the region of origin (Fig. 3b). However, the subclusters A1, B1a and B2b were largely composed of northern accessions and accessions from Valais while A2a, B1b and B2a could be considered as mixed. When only the 39 named accessions (Table 2) were considered, it was confirmed that cluster A2b was most likely to contain accessions typical for southern Switzerland (Fig. 3c). Furthermore, B1b and B2b contained accessions closely related to what was historically called the Linth type and within clusters A1, A2a, B1b and B2a, accessions mostly were of the Rheintaler/Oberlaender type. The fact that A2a contained equal numbers of accessions of Rosso and Rheintaler type indicates possible hybridization of material from northern and southern country parts.

The overall $F_{\mathrm{ST}}$ (Theta) of 0.42 (data not shown) supported the presence of subpopulations already indicated in the cluster analysis based on pairwise $D_{\mathrm{w}}$ between accession. To test the genetic relatedness of the different regions, the pairwise Cavalli-Sforza and Edwards' chord distance based on allele frequencies per region was used. The hierarchical clustering of the Swiss geographic regions of origin (Fig. 4) revealed two main groups: One clearly northern group including the regions Linth valley, Rhine valley, and Posterior Rhine and one rather southern group consisting of the Poschiavo valley, Ticino \& Mesolcino and the Anterior Rhine. Accessions from the Valais could not be assigned to any of the groups with bootstrap support meeting the criteria for display (50\% support).

The high $F_{\text {ST }}$ could also be a result of a severe bottleneck for the sub populations due to small population sizes and little genetic exchange. We aimed to elucidate if the entity of accessions or material from any specific geographic regions experienced a bottleneck in the past. The mode-shift of the allele frequency distribution away from the typical L shape (Luikart et al. 1998) was used as an indicator. According to this indicator, the entity of samples as well as most of the regional samples did not show a distortion from the L shaped distribution (Fig. 5a). The only region indicating a mode shift to frequency class 0.2 was Poschiavo (Fig. 5b).

\section{History of maize in Switzerland}

In order to support the interpretation of the genetic analysis, we reviewed the history of maize in Switzerland and its collection. The early presence of maize north of the Alps is reliably documented by German herbalists: Bock (1539; cited by Finan 1948) was the first botanist to describe maize and later Fuchs (1543) from Tuebingen (Wuerttemberg, Germany), presented the first illustration of maize in Europe. The description and illustration suggests that it was a flint type of maize (Rebourg et al. 2003) and Fuchs stated that it was growing almost in every garden. Thus flint maize was widely grown in countries north of Switzerland half a decade after the discovery of the new world. For Switzerland the first reported cultivation dates back to 1571 in Altstaetten (Rhine valley) and it was assumed that it was introduced via Hungary and Austria and therefore called "Tuerggen" or "Tirckhisch Korn" (Koblet 1965), probably related to the fact that the Ottoman Empire, associated with exotic influences, reached almost to Vienna at that time. In fact, Turkish corn was the local name for maize in many regions of Europe (compare with: Dubreuil et al. 2006). In 1650 Turkish Corn, was among the taxes collected by the church in Balgach, Rhine valley (Bilgeri 1948), indicating that maize had established as a crop. The year 1869 is mentioned by Fessler (1987) as the peak of maize cultivation in the Austrian Rhine Valley. At that time maize replaced spelt (Triticum spelta L.) as the most important crop. Maize was predominantly 
Fig. 2 Grouping of the landrace accessions and Magister on the basis of modified Rogers distance applied to Wards

hierarchical descendant analysis. Codes beginning with $C$ refer to three historical accessions. Letters and numbers on the right are identifiers for the different groups. A2 represents the cluster containing the Italian Orange Flint types. B1 contains the German Flint types. In addition to the accessions listed in Table 1 three accessions collected in 1906 were included for comparison
Heght
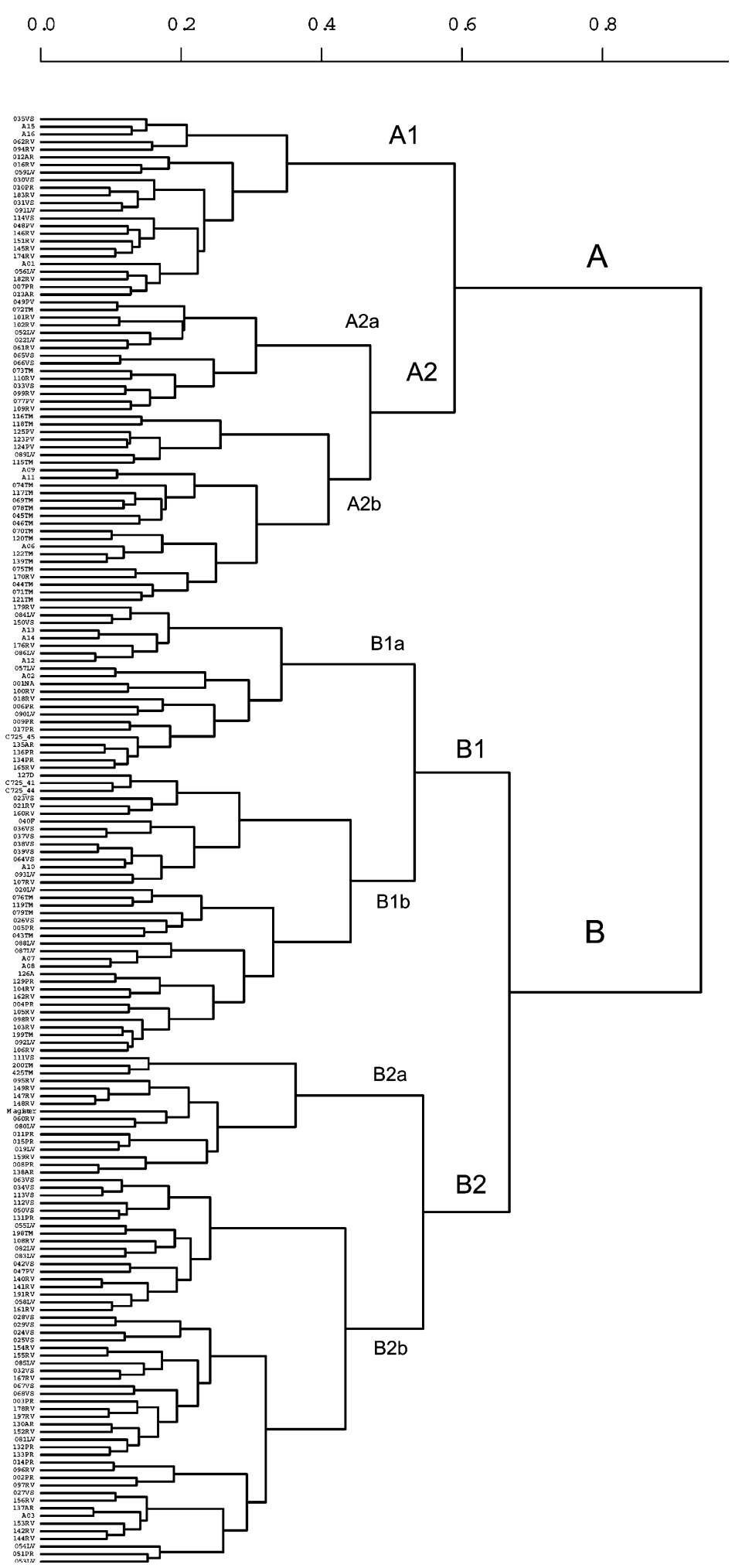
Fig. 3 The clusters formed in the hierarchical analysis according to Ward are shown with the distribution of accessions belonging to north or south of

Switzerland (a), accessions belonging to one of seven geographic regions (b) and the accessions with filed historic information (c)
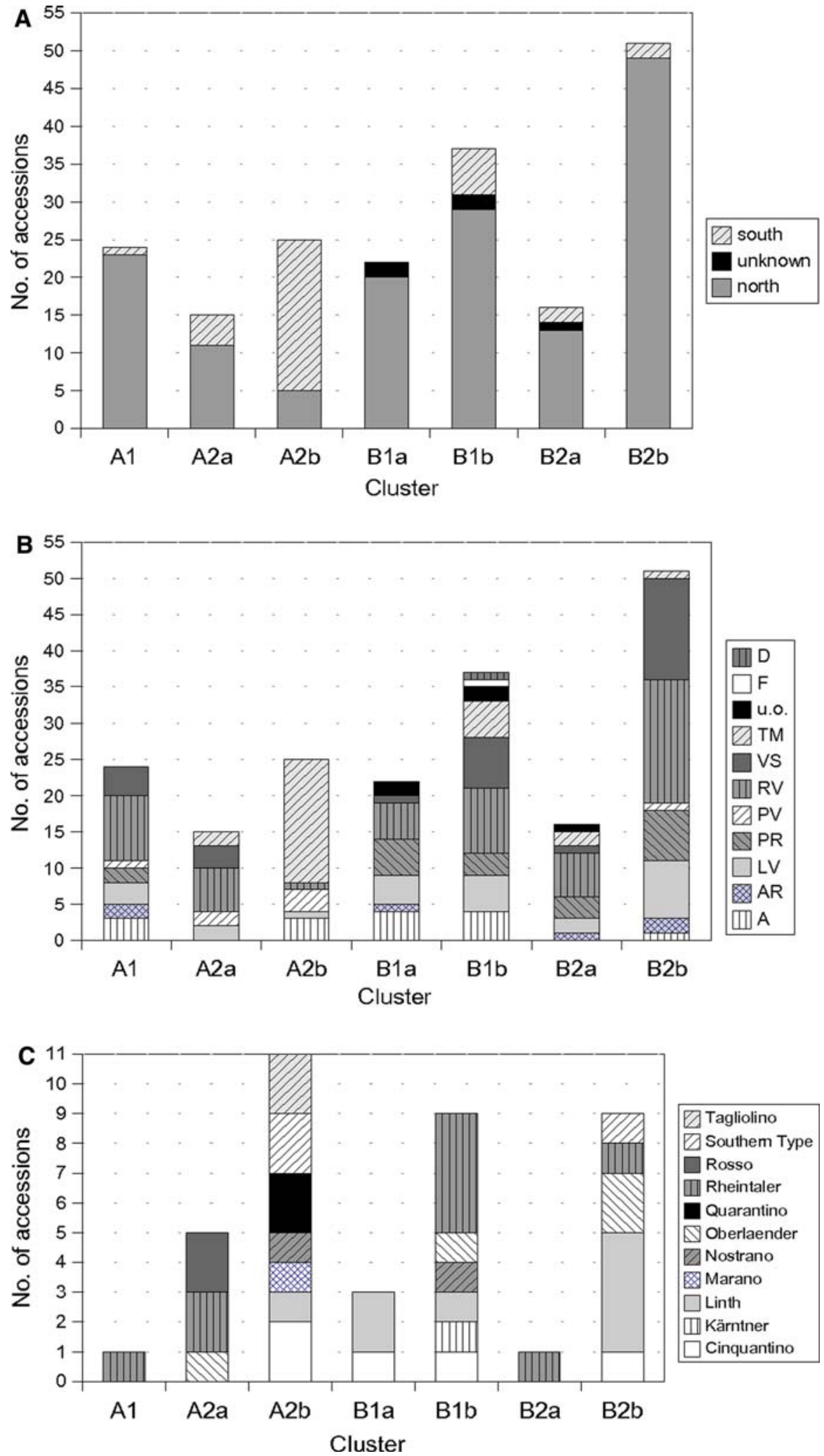
Table 2 Accessions collected early with documented historic landrace indication sorted by the cluster of the Ward dendrogram (see Fig. 4)

\begin{tabular}{|c|c|c|}
\hline Entry ETH & Landrace name & Cluster \\
\hline 091LV & Rheintaler & A1 \\
\hline 072TM & Rosso & $\mathrm{A} 2 \mathrm{a}$ \\
\hline 073TM & Rosso & $\mathrm{A} 2 \mathrm{a}$ \\
\hline 061RV & Rheintaler & $\mathrm{A} 2 \mathrm{a}$ \\
\hline 052LV & Rheintaler & $\mathrm{A} 2 \mathrm{a}$ \\
\hline $022 \mathrm{LV}$ & Oberlaender & $\mathrm{A} 2 \mathrm{a}$ \\
\hline 046TM & Bianco Cinquantino & $\mathrm{A} 2 \mathrm{~b}$ \\
\hline $120 \mathrm{TM}$ & Southern type & $\mathrm{A} 2 \mathrm{~b}$ \\
\hline $118 \mathrm{TM}$ & Cinquantino & $\mathrm{A} 2 \mathrm{~b}$ \\
\hline 070TM & Tagliolino & $\mathrm{A} 2 \mathrm{~b}$ \\
\hline $122 \mathrm{TM}$ & Marano & $\mathrm{A} 2 \mathrm{~b}$ \\
\hline 075TM & Nostrano & $\mathrm{A} 2 \mathrm{~b}$ \\
\hline 069TM & Quarantino & $\mathrm{A} 2 \mathrm{~b}$ \\
\hline 071TM & Tagliolino & $\mathrm{A} 2 \mathrm{~b}$ \\
\hline 045TM & Southern type & $\mathrm{A} 2 \mathrm{~b}$ \\
\hline 089LV & Linth & $\mathrm{A} 2 \mathrm{~b}$ \\
\hline 078TM & Quarantino & $\mathrm{A} 2 \mathrm{~b}$ \\
\hline 009PR & Cinquantino & B1a \\
\hline 086LV & Red Linth & B1a \\
\hline 057LV & Linth & B1a \\
\hline $119 \mathrm{TM}$ & Cinquantino & $\mathrm{B} 1 \mathrm{~b}$ \\
\hline 076TM & Nostrano & $\mathrm{B} 1 \mathrm{~b}$ \\
\hline $126 \mathrm{~A}$ & Kärntner & $\mathrm{B} 1 \mathrm{~b}$ \\
\hline 106RV & Rheintaler & $\mathrm{B} 1 \mathrm{~b}$ \\
\hline 107RV & Rheintaler & $\mathrm{B} 1 \mathrm{~b}$ \\
\hline 021RV & Rheintaler & $\mathrm{B} 1 \mathrm{~b}$ \\
\hline 020LV & Oberlaender & $\mathrm{B} 1 \mathrm{~b}$ \\
\hline 088LV & Linth & $\mathrm{B} 1 \mathrm{~b}$ \\
\hline 103RV & Rheintaler & $\mathrm{B} 1 \mathrm{~b}$ \\
\hline 080LV & Rheintaler & $\mathrm{B} 2 \mathrm{a}$ \\
\hline 047PV & Cinquantino & $\mathrm{B} 2 \mathrm{~b}$ \\
\hline 003PR & Southern type & $\mathrm{B} 2 \mathrm{~b}$ \\
\hline 081LV & Oberlaender & $\mathrm{B} 2 \mathrm{~b}$ \\
\hline 082LV & Small Rheintaler & $\mathrm{B} 2 \mathrm{~b}$ \\
\hline $053 \mathrm{LV}$ & Linth & $\mathrm{B} 2 \mathrm{~b}$ \\
\hline $085 \mathrm{LV}$ & Linth & $\mathrm{B} 2 \mathrm{~b}$ \\
\hline 096RV & Linth & $\mathrm{B} 2 \mathrm{~b}$ \\
\hline $055 \mathrm{LV}$ & Oberlaender & $\mathrm{B} 2 \mathrm{~b}$ \\
\hline 083LV & Linth & $\mathrm{B} 2 \mathrm{~b}$ \\
\hline
\end{tabular}

A full list of accessions is available at (www.bdn.ch) cultivated for human consumption and region-specific traditional dishes where associated with a certain grain type. White "Rheintaler" grains were preferred for the porridge breakfast dish "Ribel" in the Rhine valley; yellow to orange grains were the basis for the porridge "Polenta" of the Ticino and the Posterior Rhine region (Domleschg). Latest at the beginning of the ninetieth century, with the construction of the majority of today's alpine passes, the different regions of Switzerland were strongly interconnected. Climatic constraints as well as preferences of the local growers must have been the major forces separating the different landrace populations.

At the beginning of the twentieth century maize cultivation decreased, although maize landraces experienced a short revival during World War Two (WWII) with an almost doubled area of cultivation (Tanner 2005). After WWII, maize cultivation in the North went down almost to zero; it only increased again in the 1960s due to the introduction of modern hybrids for silage and fodder production (Koblet 1965). Apparently the Swiss landraces did not disappear as a consequence of the replacement by modern material. According to documents from the collection phase, the production of polenta maize in Ticino and Mesolcino (together here referred to as Ticino), was reduced prior to WWII, and most polenta flour was imported from Argentina. During WWII, the maize production in Ticino also increased, but mostly imported open pollinated varieties from Italy, like Marano and Nostrano dell' Isola were cultivated. Based on kernel morphology the Swiss landraces were all of flint type.

History of the collection

The Swiss collection started prior to a variety trial for silage quality by Wahlen and Wagner (1934). Based on the results of this first evaluation, a systematic collection of Swiss accessions was initiated in the 1940s. The goal of the collection was to conserve landraces and to integrate those of a high breeding value into the Swiss breeding program. Besides the traditional autochthonous landraces, exotic material, i.e. allochthonous landraces, was requested as well. In the 1940s, the period in which most of the landraces 
Fig. 4 Consensus tree of all the different groups of geographic origin in Switzerland after 1,000 bootstrap replicates of a UPGMA dendrogram based on the pairwise CavalliSforza and Edwards' chord distances. Numbers at the edges indicate the percentage of bootstrap support
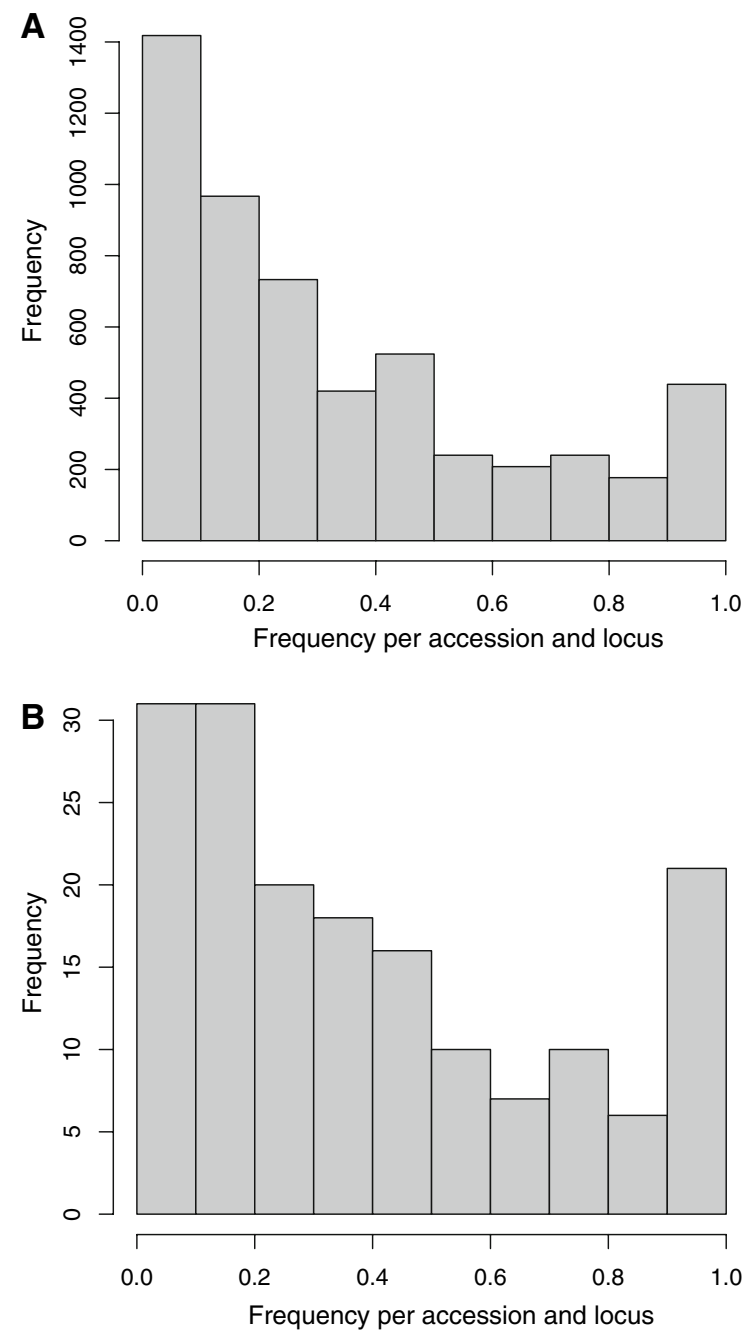

Fig. 5 The frequency distributions of alleles per accession and locus visualized for the total population (a) and for the Poschiavo valley (b)

were collected, 69 landraces entered the gene bank. While most accessions were not explicitly named, the passport data of 39 accessions supplied information

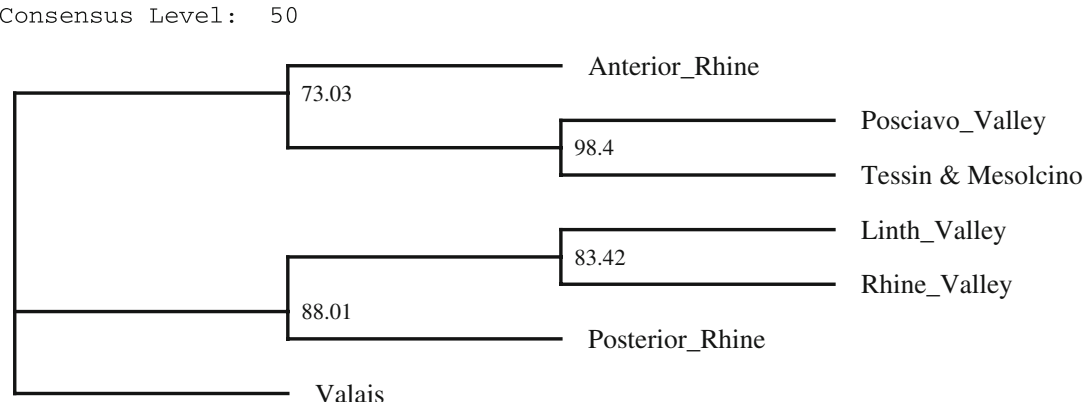

on the names and some basic characteristics (Table 2). Based on these data and results from variety trials in the $1940 \mathrm{~s}$, at least two main complexes can be distinguished: a southern complex with mostly small, yellow, orange, or red grains and more than 12 kernel rows per ear, and a northern complex with white to yellow kernel types with $8-12$ kernel rows. The northern landraces and their names were better documented: Oberländer (medium late, white kernels, 8-12 rows), Rheintaler (medium early, mostly white kernels, 10-12 rows), and Linthmais (medium early, creamy to yellow kernels, long 8-10 rows). According to passport data, the Rheintaler complex can be subdivided into a short, earlier type, a tall, later type, and a so-called Oberländer. For the southern accessions, there was almost no information on their identity. Besides various landraces named with the commonly used expression "Nostrano", (Italian for "home-bred"), two landraces named Tagliolino (070TM and 071TM) and Scaiolo (116TM) were reported, but their habitus was not clearly defined for Switzerland.

The collectors reported the presence of many foreign landraces within Switzerland, some of which also entered the Swiss gene bank. Besides Marano (122TM), some landraces from Ticino, i.e. Quarantino (078TM), Cinquantino (119TM) and Bianco Cinquantino (046TM), have typical names of landraces from Italy (Rebourg et al. 2001) and suggest an Italian provenance. However, since these expressions refer to the maturity time (four and five months, respectively) to our knowledge the names do not point to a specific region of origin.

Even though the information supplied with the collected material was not always assigned to the individual accessions it provided information about the landraces planted in a specific region. From these data there is evidence that a vast amount of 
allochthonous landraces was collected together with the autochthonous ones and in some regions they had been cultivated for decades before the collection. For example, the white Rheintaler was documented to be grown in all northern valleys, i.e. also the region of Domleschg, the Linth plane, and Schwyz, for at least 20 years before the collection. For the Linth area, an increased hybridization of the autochthonous landraces with Rheintaler but also with unknown darkcoloured accessions was explicitly mentioned as a cause of an increased variability of the material grown in that region at the time of the collection. This documents the strong exchange of material as well as the hybridization between different landraces.

\section{Discussion}

The genetic differentiation of Swiss landraces

The average number of alleles per accession of 2.8 in our study was lower than what was reported for ancestral open pollinated populations from North America; Ho et al. (2005) reported values of 3.25 for Northern Flints and Southern Dents as well as 3.87 for Corn Belt Dents. However, subgroups of the material we analyzed showed similarly high values: 3.4 for the Anterior Rhine region and 3.9 for three Swiss historic accessions. This indicates a level of allelic diversity comparable to open pollinated populations from North America. The gene diversity (0.78) and the alleles per locus (13.7) were comparable to the North American material: Values of American material were slightly lower for the expected heterozygosity, i.e. gene diversity ( 0.71 and 0.73 for dents and flints, respectively), and slightly higher for the number of alleles per locus (14 and 15 for dents and flints, respectively; Ho et al. 2005). Consequently, the entity of Swiss accessions can be considered genetically diverse while single accessions show a tendency to reduction of diversity measured by the number of alleles. The average values for pairwise $D_{\mathrm{w}}$ of 0.39 (Reif et al. 2005b, 2006) reported for European flint material and 0.35 for Mexican maize races were higher than the 0.18 reported here. However the method applied here was capable of identifying four independent samples of the same accession as being closely related compared to samples of different accessions (Eschholz et al.
2008). This was considered proof that ten SSRs can be sufficient to distinguish landrace accessions. It is common practice to trade a reduced number of individuals per accession or a reduced number of SSR loci for the ability to screen many accessions in the frame work of limited resources (Labate et al. 2003; Ho et al. 2005).

The high $F_{\mathrm{ST}}(0.42)$ observed in our study indicated that gene flow among different landraces was limited in Switzerland. This finding is in accordance to our initial hypothesis but surprising regarding the documented substantial seed exchange among geographic regions at least in the north of the country. $F_{\mathrm{ST}}$ values for maize populations in America ranged from 0.003 (Mexico, Pressoir and Berthaud 2004) to 0.35 (USA, Northern Flints, González Ugalde 1997). Thus, the differences among Swiss landraces may be similar as reported for Northern Flints and the individual accessions may even be more clearly separated than they are in Northern Flint.

A reason for the high $F_{\mathrm{ST}}$ values of Swiss landraces might be the farmers' practice to choose few ears as source of seeds for the next year which might have resulted in founder effects leading to fixation of common alleles. Such a practice is not unusual; it was also reported for South America (Lia et al. 2007). Moreover, selection for earliness in the northern areas could have narrowed the genetic base of northern accessions. But this was probably not the case, since the genetic diversity and the number of alleles per accession in the Swiss material appeared similar in the North and the South. Hybridization between populations of different regions occurred frequently. There is historic evidence that growers from the north continuously tested material from Ticino (in the South), and that even the later material reached maturity when autumn foehn prolonged the vegetation period. Although the growing regions were geographically separated, they were situated along major trading routes and gene flow among different regions certainly occurred. The results of the cluster analysis support the idea of seed exchange, especially within the northern valleys, while accessions from Ticino and Poschiavo built the most concise group (cluster A2b) within the whole collection. The lack of groups representing single landraces like, for example, Rheintaler or Linth maize may be due to (1) the reported exchange and cross 
hybridization of the material, and (2) the relatively low number of markers used. However, the geographically remote Poschiavo valley harboured a number of region-specific alleles (Table 1) and was therefore genetically separated from the rest of the country. For this region, also a strong exchange of material with adjacent Italy has to be questioned since the allele frequency distribution of material from Poschiavo showed a distortion from the Lshaped distribution, suggesting a recent bottleneck (Luikart et al. 1998; Luikart and Cornuet 1998). For the entity of accessions under investigation such a distortion was not observed. The same was true in a study on numerous maize inbred lines from all over the world (Liu et al. 2003).

The relationship to neighbouring regions

Two associations of the Swiss material with material of the neighbouring countries are particularly significant, when geographic, morphological, and genetic data are considered:

The northern accessions are related to the Northern European complex including German and NorthEastern European Flint. This is evidenced by (1) a similar ear morphology as the Northern Flints ("long and slender with 8 to 10 rows of wide, crescendshaped kernels"; Brown and Anderson 1947), and (2) the fact that the "Northern Swiss" sub cluster B1, contained landraces belonging to the Northern European complex, i.e. the Rheinthaler, Jaune de Bade (also known as Gelber Badischer Landmais; 127D and C725_45) and Vorarlberger Weisser (also known as white Rheintaler).

The southern types from Ticino and Poschiavo are related to the Italian Orange Flint group. This is evidenced by (1) the documented influence of Italian landraces in that region, (2) the similar ear morphology with small, hard kernels and a high number of kernel rows, and (3) by the fact that the "Southern Swiss" sub cluster A2 contained the landrace Marano (122TM) which in turn belongs to the Italian Orange Flint group (Rebourg et al. 2001). Besides the Italian Orange Flint group, other material like the Pearl White Flints from the Veneto region (north-eastern Italy) was likely introduced into Switzerland (Brandolini 1970; Brandolini and Brandolini 2001). These could have been one of the genetic sources of the white Rheintaler population.
The reason for the associations displayed in Fig. 4 may lie in connections between the different regions in the form of mountain passes. Because the different passes were frequented at different times in the history of the Alps the following reasoning should be regarded as based on our genetic data. The fact that accessions from the region Anterior Rhine are closely connected to accessions from Ticino and Poschiavo valley could be explained by trade across the Lukmanier Pass connecting Ticino and Anterior Rhine. The proximity of Ticino to Poschiavo probably was caused by exchange between the two regions south of the main Alpine ridge through Italy which would also explain the predominant cultivation of Italian types of maize in these regions. Similarly, Linth and Rhine valley are connected to Posterior Rhine by a route leading to Via Mala-San Bernardino enabling exchange of seeds resulting in high genetic similarity of these regions. This may also explain why yellow kernels and Polenta were popular in the Domleschg area in the Posterior Rhine region. The fact that the Valais did not show a clear connection to any specific region may have been caused by frequent exchange with both the other regions the southern and the northern one.

In summary, two major groups were identified within the examined material: one related to the Northern European Flint group, comprising mostly accessions from the northern regions and one related to the Italian Orange Flint group, inclosing mostly material from the southern valleys. Especially the genetic diversity present within the northern Swiss and Austrian material can serve as a resource for broadening the genetic basis of flint maize in European plant breeding. Morphologic differences for accessions from different regions were shown for root and shoot morphology as well as for early vigour (Peter 2007; Peter et al. 2009). In order to use this resource efficiently, further genotyping with core markers is needed to identify material with little representation in the European germplasm collection.

Acknowledgments We would like to thank Peer Schilperoord for the supply of historic documents as well as Geert Kleijer and Mathias Menzi for their critical comments. Furthermore, we thank our Austrian partners Christian Partl and Richard Dietrich for supplying seed. The project was funded by the "Diversity in Agriculture Campaign Plants" of the Swiss Federal Office of Agriculture. 


\section{References}

Bilgeri B (1948) Der Getreidebau im Lande Vorarlberg. Montfort 2:65-99

Brandolini A (1970) Razze Europee di mais. Maydica 15:5-27

Brandolini A, Brandolini A (2001) Classification of Italian maize (Zea mays L.) germplasm. Plant Genet Resour Newsl 126:1-11

Brown WL, Anderson E (1947) The northern flint corns. Ann Mo Bot Gard 34:1-29. doi:10.2307/2394437

Camus-Kulandaivelu L, Veyrieras J-B, Madur D, Combes V, Fourmann M, Barraud S, Dubreuil P, Gouesnard B, Manicacci D, Charcosset A (2006) Maize adaptation to temperate climate: relationship between population structure and polymorphism in the Dwarf8 gene. Genetics 172:2449-2463. doi:10.1534/genetics.105.048603

Cavalli-Sforza LL, Edwards AW (1967) Phylogenetic analysis. Models and estimation procedures. Am J Hum Genet 19:233-257

De Galarreta JIR, Alvarez A (2001) Morphological classification of maize landraces from northern Spain. Genet Resour Crop Evol 48:391-400. doi:10.1023/A:1012074 606561

Dubreuil P, Charcosset A (1999) Relationships among maize inbred lines and populations from European and NorthAmerican origins as estimated using RFLP markers. Theor Appl Genet 99:473-480. doi:10.1007/s00122005 1259

Dubreuil P, Warburton M, Chastanet M, Hoisington D, Charcosset A (2006) More on the introduction of temperate maize into Europe: large-scale bulk SSR genotyping and new historical elements. Maydica 51:281-291

Eschholz TW, Peter R, Stamp P, Hund A (2008) Genetic diversity of Swiss maize (Zea mays L. ssp. mays) assessed with individuals and bulks on agarose gels. Genet Resour Crop Evol 55:971-983. doi:10.1007/s10722-007-9304-8

Fessler H (1987) Mühlen und Wasserräder in ihrer wirtschafts-, rechts- und technikgeschichtlichen Bedeutung mit besonderer Berücksichtigung des Mühlenwesens in Vorarlberg. Universität Innsbruck, Innsbruck

Finan JJ (1948) Maize in the great herbals. Ann Mo Bot Gard 35:149-191. doi: $10.2307 / 2394391$

Fuchs L (1543) New Kreüterbuch, German edition (De Historia Stirpium commentarii insignes, First edition 1542 in Latin), Basel

Gauthier P, Gouesnard B, Dallard J, Redaelli R, Rebourg C, Charcosset A, Boyat A (2002) RFLP diversity and relationships among traditional European maize populations. Theor Appl Genet 105:91-99. doi:10.1007/s00122-0020903-7

González Ugalde WG (1997) Genetic characterisation of Northern flints and flours maize (Zea mays L. spp. mays) with isozyme, SSR and morphological markers. Diss. Abstr. Int. 58-11B:5706, Iowa State University, Ames

Gouesnard B, Dallard J, Bertin P, Boyat A, Charcosset A (2005) European maize landraces: genetic diversity, core collection definition and methodology of use. Maydica 50:225-234

Ho JC, Kresovich S, Lamkey KR (2005) Extent and distribution of genetic variation in US maize: historically important lines and their open-pollinated dent and flint progenitors. Crop Sci 45:1891-1900. doi:10.2135/cropsci 2003.0494

Janick J, Caneva G (2005) The first images of maize in Europe. Maydica 50:71-80

Jobb G, von Haeseler A, Strimmer K (2004) TREEFINDER: a powerful graphical analysis environment for molecular phylogenetics. BMC Evol Biol 4:18. doi:10.1186/14712148-4-18

Koblet R (1965) Der landwirtschaftliche Pflanzenbau, unter besonderer Berücksichtigung der schweizerischen Verhältnisse. Birkhäuser Verlag, Basel

Labate JA, Lamkey KR, Mitchell SE, Kresovich S, Sullivan H, Smith JSC (2003) Molecular and historical aspects of corn belt dent diversity. Crop Sci 43:80-91

Lawrence CJ, Dong Q, Polacco ML, Seigfried TE, Brendel V (2004) MaizeGDB, the community database for maize genetics and genomics. Nucleic Acids Res 32:393-397. doi:10.1093/nar/gkh011

Lia V, Confalonieri V, Ratto N, Hernandez J, Alzogaray A, Poggio L, Brown T (2007) Microsatellite typing of ancient maize: insights into the history of agriculture in southern South America. Proc R Soc B: Biol Sci 274:545554

Liu K, Muse SV (2005) Powermarker: an integrated analysis environment for genetic marker analysis. Bioinformatics 21:2128-2129. doi:10.1093/bioinformatics/bti282

Liu K, Goodman M, Muse S, Smith JS, Buckler E, Doebley J (2003) Genetic structure and diversity among maize inbred lines as inferred from DNA microsatellites. Genetics 165:2117-2128

Luikart G, Cornuet J-M (1998) Empirical evaluation of a test for identifying recently bottlenecked populations from allele frequency data. Conserv Biol 12:228-237. doi: 10.1046/j.1523-1739.1998.96388.x

Luikart G, Allendorf FW, Cornuet JM, Sherwin WB (1998) Distortion of allele frequency distributions provides a test for recent population bottlenecks. J Hered 89:238-247. doi:10.1093/jhered/89.3.238

Messmer MM, Melchinger AE, Boppenmaier J, Brunklausjung E, Herrmann RG (1992) Relationships among early European maize inbreds. 1. Genetic diversity among flint and dent lines revealed by RFLPs. Crop Sci 32:13011309

Peter R (2007) Early vigour of swiss maize landraces (Zea mays L.) in cool environments-agronomic performance and root characteristics. Diss. ETH, Zurich

Peter R, Eschholz TW, Stamp P, Liedgens M (2009) Swiss flint maize landraces - a rich pool of variability for early vigour in cool environments. Field Crops Res 110:157-166. doi:10.1016/j.fcr.2008.07.015

Pressoir G, Berthaud J (2004) Patterns of population structure in maize landraces from the central valleys of Oaxaca in Mexico. Heredity 92:88-94. doi:10.1038/sj.hdy.6800387

$\mathrm{R}$ development core team (2004) R: a language and environment for statistical computing. $\mathrm{R}$ foundation for statistical computing, Vienna

Rebourg C, Dubreuil P, Charcosset A (1999) Genetic diversity among maize populations: bulk RFLP analysis of 65 accessions. Maydica 44:237-249 
Rebourg C, Gouesnard B, Charcosset A (2001) Large scale molecular analysis of traditional European maize populations. Relationships with morphological variation. Heredity 86:574-587. doi:10.1046/j.1365-2540.2001.008 69. $\mathrm{x}$

Rebourg C, Chastanet M, Gouesnard B, Welcker C, Dubreuil P, Charcosset A (2003) Maize introduction into Europe: the history reviewed in the light of molecular data. Theor Appl Genet 106:895-903

Reif J, Hamrit S, Heckenberger M, Schipprack W, Maurer H, Bohn M, Melchinger A (2005a) Trends in genetic diversity among European maize cultivars and their parental components during the past 50 years. Theor Appl Genet 111:838-845. doi:10.1007/s00122-005-0004-5

Reif JC, Hamrit S, Heckenberger M, Schipprack W, Peter Maurer H, Bohn M, Melchinger AE (2005b) Genetic structure and diversity of European flint maize populations determined with SSR analyses of individuals and bulks. Theor Appl Genet 111:906-913. doi:10.1007/ s00122-005-0016-1

Reif J, Warburton ML, Xia XC, Hoisington DA, Crossa J, Taba $\mathrm{S}$, Muminovic J, Bohn M, Frisch M, Melchinger AE (2006) Grouping of accessions of Mexican races of maize revisited with SSR markers. Theor Appl Genet 113:177185. doi:10.1007/s00122-006-0283-5
Revilla P, Soengas P, Malvar RA, Cartea ME, Ordas A (1998) Isozyme variation and historical relationships among the maize races of Spain. Maydica 43:175-182

Revilla P, Soengas P, Cartea ME, Malvar RA, Ordas A (2003) Isozyme variability among European maize populations and the introduction of maize in Europe. Maydica 48:141152

Saitou N, Nei M (1987) The neighbor-joining method: a new method for reconstructing phylogenetic trees. Mol Biol Evol 4:406-425

Sokal RR, Michener CD (1958) A statistical method for evaluating systematic relationships. Univ Kans Sci Bull 28:1409-1438

Tanner A (2005) Anbauschlacht. Historisches Lexikon der Schweiz (HLS). Historisches Lexikon der Schweiz (HLS)

Wahlen FT, Wagner S (1934) Sortenanbauversuche mit Silomais. 1930/1932. Separatabdruck aus dem Landwirtschaftlichen Jahrbuch der Schweiz 1934

Ward JH Jr (1963) Hierarchical grouping to optimize an objective function. J Am Stat Assoc 58:236-244. doi: $10.2307 / 2282967$

Weir BS (1996) Genetic data analysis II. Sinauer, Sunderland

Wright S (1978) Variability within and among natural populations. Evol Genet Populations 4:580 